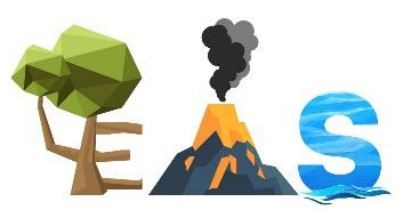

\title{
TRAUMA FOR THE USE OF MALADAPTIVE PROSTHESIS: CLINICAL CASE
}

\section{REPORT}

\author{
Richardson Gray Monteiro de Tolêdo MONGUILHOTT ${ }^{\mathbf{1}}$; José Cavalcante DANTAS \\ NETO $^{2}$; Rafael Douglas Fernandes do NASCIMENTO³; Viviane Maria Gonçalves de \\ FIGUEIREDO ${ }^{4}$; Martin Lindsey CHRISTOFFERSEN ${ }^{5}$
}

\author{
${ }^{1}$ Graduando em Odontologia/Centro Universitário Maurício de Nassau (UNINASSAU/PB), Brasil. E-mail: \\ richardson.monteiro@gmail.com \\ ${ }^{2}$ Graduando em Odontologia/UNINASSAU/PB, Brasil. E-mail: netto.pm@gmail.com \\ ${ }^{3}$ Graduando em Odontologia/UNINASSAU/PB, Brasil. E-mail: rafaeldouglasfilho123@gmail.com \\ ${ }^{4}$ Professora em Odontologia/UNINASSAU/PB, Brasil; Especialista em Prótese Dentária/Centro Odontológico \\ de Estudos e Pesquisas (COESP), Brasil; Mestra em Diagnostico Bucal/Universidade Federal da Paraíba \\ (UFPB), Brasil; Doutora em Odontologia Restauradora/Prótese Dentária/Universidade Estadual Paulista \\ (UNESP), Brasil. E-mail: vivi_mfigueiredo@yahoo.com.br \\ ${ }^{\mathbf{5}}$ Bacharel e Licenciado em Ciências Biológicas/Universidade de São Paulo (USP), Brasil; Doutor em Ciências \\ Biológicas/USP, Brasil; Professor Titular/UFPB, Brasil. E-mail: mlchrist@dse.ufpb.br
}

\begin{abstract}
The purpose of this study is to address traumas in the oral cavity due to the use of removable or total prostheses, that either fit poorly into the oral cavity or are incorrectly sanitized by the patient. We highlight the need for a Surgical Dentist to perform possible corrections, and to perform a follow-up of the patient after the procedure. It is noteworthy that lesions such as ulcers and gum overgrowths can be avoided satisfactorily if the dental surgeon is able to perform an adequate treatment after the installation. A dental surgeon should be qualified to establish the real need for correction. His close interaction with the patient is the main point for the success of the work.
\end{abstract}

Keywords: Prosthesis; Surgeon; Dentistry.

\section{TRAUMA PELO USO DE PRÓteSE MAL ADAPTADA: RELATO DE CASO CLÍNICO}

Resumo. O intuito deste estudo é abordar traumas que estão na cavidade oral, decorrente do uso de próteses, seja ela removível ou total, com adaptação ruim ou má higienização pelo paciente, destacando a necessidade da atuação de um Cirurgião Dentista para realizar possíveis correções, orientações e acompanhamento do paciente após o procedimento. Destaca-se que lesões como úlceras e hiperplasias conseguem ser evitadas de forma satisfatória caso o cirurgião dentista consiga realizar um tratamento adequado após a instalação, observando a real necessidade de correção. A demonstração de uma estreita interação com o paciente constitui o ponto principal para o sucesso do trabalho. 
Palavras-chave: Prótese; Cirurgião; Odontologia.

\section{TRAUMA POR EL USO DE PRÓTESIS MAL ADAPTADA: RELATO DE CASO CLÍNICO}

Resumen. El objetivo de este estudio es abordar traumas que están en la cavidad oral, debido al uso de prótesis, sea removible o total, con adaptación mala o mala higienizada por el paciente, destacando la necesidad de la actuación de un Cirujano Dentista para realizar posibles correcciones, orientaciones y orientaciones seguimiento del paciente después del procedimiento. Se destaca que lesiones como úlceras e hiperplasias logran ser evitadas de forma satisfactoria si el CD logra realizar un tratamiento adecuado después de la instalación observando la real necesidad de corrección, demostrando la estrecha interacción con el paciente como punto principal para el éxito del trabajo.

Palabras clave: Prótesis; Cirujano; Odontología.

\section{INTRODUCTION}

Prosthetic Dentistry is a specialty that aims to guarantee the oral rehabilitation of areas of the oral cavity that lack teeth, by way of implanting artificial devices (DESPLATS; KEOGH, 1998). The objectives are to eliminate diseases in the oral cavity, to restore damaged areas in the oral cavity in general, and to promote the maintainance of teeth that still remain in the oral mucosa (CARR; MCGIVENY; BROWN, 2005).

In patients using dental prostheses, it has been common to find ulcers, inflamed gum overgrowths, candidiasis, and other injuries, caused mainly by badly fitting prostheses (CARR; MCGIVENY; BROWN, 2005; GOIATO et al., 2005).

\section{LITERATURE REVISION}

The success in the implementation of a partial dental prosthesis is directly related with the clinical and laboratorial stages of preparing the prosthesis, and on the subsequent coparticipation of the patient, that needs to maintain a satisfactory buccal sanitation (CONTI et al., 1991).

Lesions in the buccal mucosa are prevalent in cases of patients using removable prostheses. Among the common lesions we highlight candidiasis, inflammed gum overgrowths, and traumatic ulcers. Frequently the incidence of these lesions were due to the patient being unaware of the necessity of following rules of sanitation and of adequate use, such as frequency and extent of use (GONÇALVES et al., 2011). 
With the onset of old age, there occurs a reduction in the salivar flux, which may occasionally provoque pain, adherence of the tong onto the base of the prostheses, or lack of retention of the device, all of which may contribute to form lesions in the buccal cavity (TELES, 2010).

Taking the above points into consideration, the aim of this article is to document a case of trauma provoked by a badly fitting dental prosthesis.

\section{CLINICAL CASE REPORT}

The patient, Mr. J.S.F, aged 51 years old, uses a prosthetic model for over 10 years. He reported a great difficulty to adapt to his old prosthesis. The prosthesis used by this individual revealed several problems, such as its design, which contributed to the difficulty reported by the patient in chewing. It was also oberved that his speech was impaired. The phonetic changes were provoked by the incorrect placement of the prosthesis in the mouth. The patient also had aesthetical complaints. The prosthesis made the face appear smaller, which caused apparent aging. Added to these problems, the prosthesis had problems in its physical construction, provoking lesions in areas of the gum that made contact with the dental device, producing daily injuries on the roof of the buccal cavity when chewing (Figs. 1, 2, 3). All these problems compromised the well beying of the patient, and in the long run could provoque more serious pathologies.

To solve this problem, the scheme "etyology, pathology and treatment for cases of prosthesis traumatism" was followed (Fig. 4). Due to the ulcerations observed in the patient, a new prosthesis was made, which brough relief to the patient. 


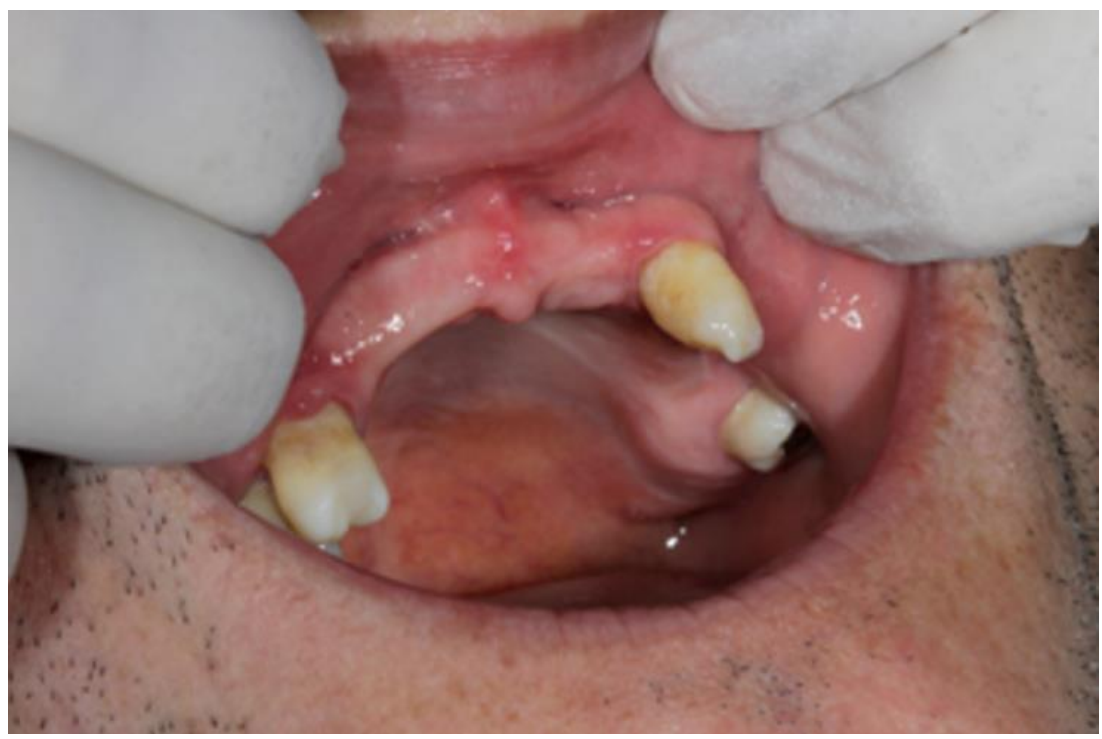

Figure 1. Condition of soft tissue with signs of trauna in the palate and at the back of the vestibule. Source: The authors.

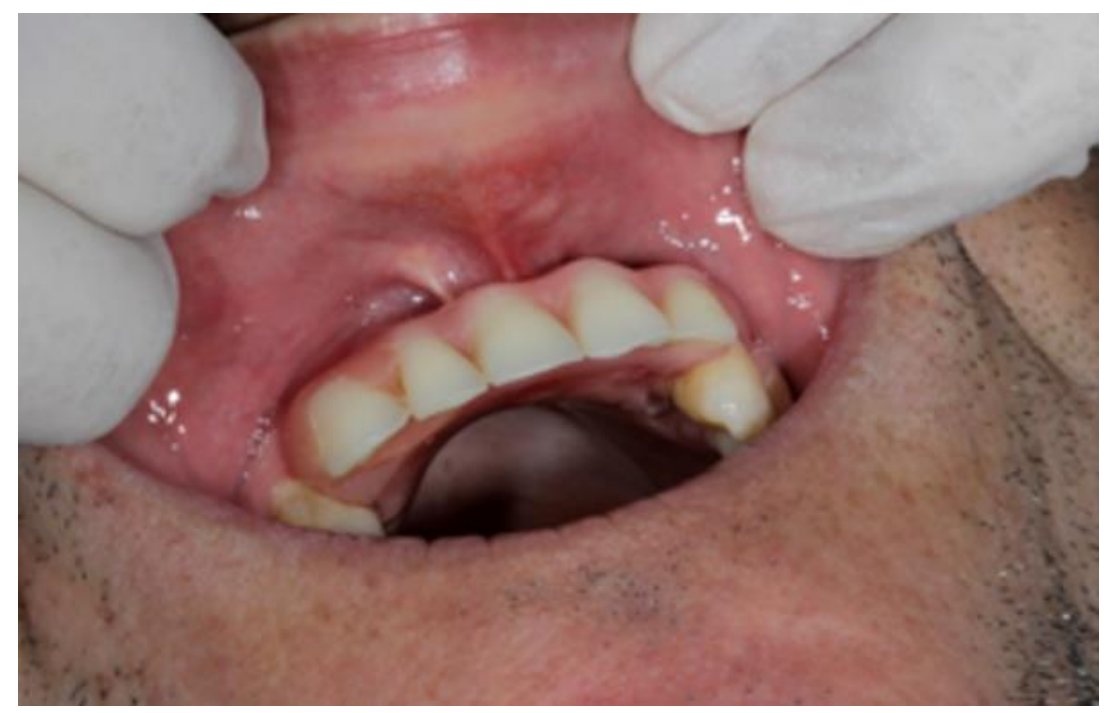

Figure 2. Prosthesis in position. Source: The authors. 


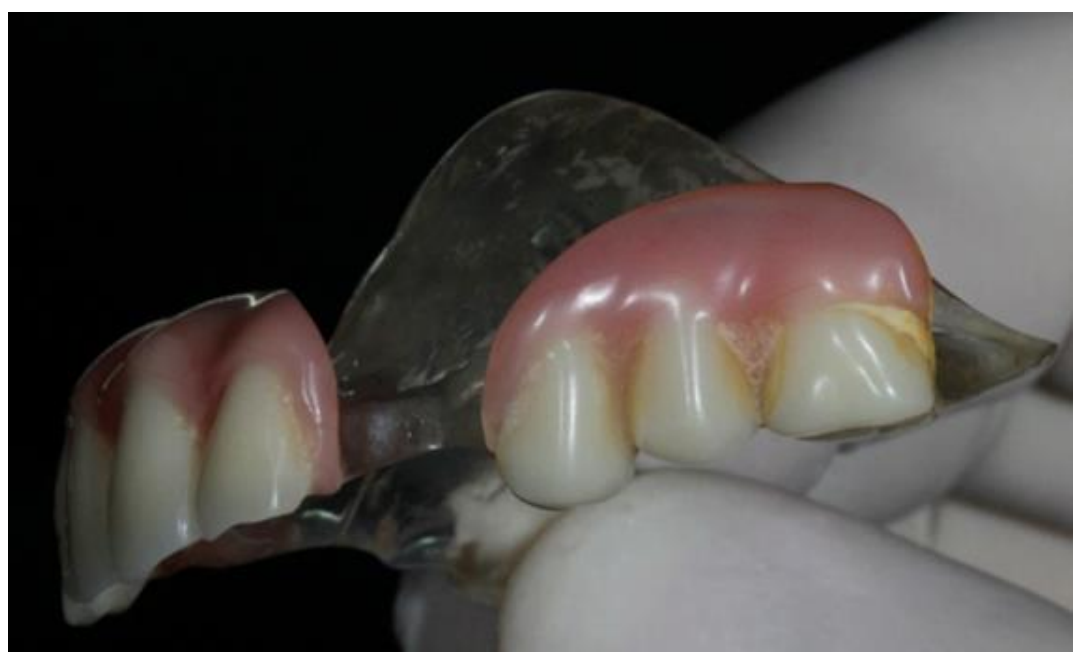

Figure 3. Unsatisfactory condition of prosthesis, indicating worn acrylic resine, short teeth, and accumulation of food remains. Source: The authors.

\section{Unsatisfactory prosthesis}

\section{Tissue trauma}

\section{Removal of the causative factor: Preparation of new prosthesis}

Figure 4. Etiology, pathology and treatment for conditions of prostheis traumatism. Source: The authors.

\section{CONCLUSIONS}

Lesions usually receive a favorable prognoses. There are no reports of malignous lesions, yet it is necessary for the Surgical Dentist to intervene in order to contain the progression of the lesion. He is required to make the necessary adjustments and to produce a new prosthesis.

\section{REFERENCES}

CARR, A.B; MCGIVENY, G.P.; BROWN, D.T. Removable partial prosthodontics. 11. ed., Missouri: Elsevier Mosby, 2005.

CONTI, P.C.R.; VALLE, A.L.; FERREIRA, P.M.; CONTI, J.V.; CURY, M.M.; TORRES, S.C. Avaliação clínica da condição de coroas totais e próteses fixas com mais de um ano de 
permanência na boca. Revista de Odontologia, Universidade de São Paulo, São Paulo, v. 5, n. 1, p. 25-28, 1991.

DESPlATS, E.; KEOGH, T. Protesis parcial removible. 1 ed. Madrid: Harcourt; 1998 GOIATO, M.C.; CASTELliONE, L.; SANTOS, D.M.; GENNARI FILHO, H.; ASSUNÇÃO, W.G. Oral injuries caused by the usage of removable prosthesis. Pesquisa Brasileira em Odontopediatria e Clínica Integrada, v. 5, n. 1, p. 85-90, 2005.

GONÇALVES, L.F.F.; SILVA NETO, D.R.; BONAN, R.F.; CARLO, H.L.; BATISTA, A.U.D. Complete and partial removable dentures cleansing methods, Revista Brasileira de Ciências da Saúde, João Pessoa, v. 15; n. 1, p. 87-94, 2011.

TELES, J.A.C.F. Lesões na cavidade oral associadas ao uso de prótese parcial removível. 46 f. Monografia (Licenciada em Medicina Dentária)-Universidade Fernando Pessoa, Porto, 2010. 